\title{
Formulation and Cytotoxicity of Ribosome-Inactivating Protein Mirabilis Jalapa L. Nanoparticles Using Alginate-Low Viscosity Chitosan Conjugated with Anti-Epcam Antibodies in the T47D Breast Cancer Cell Line
}

\author{
Psycha Anindya Wicaksono $^{1}$, Sismindari2 ${ }^{2 *}$, Ronny Martien ${ }^{2}$, Hilda Ismail ${ }^{2}$
}

\begin{abstract}
Ribosome-inactivating protein (RIP) from Mirabilis jalapa L. leaves has cytotoxic effects on breast cancer cell lines but is less toxic towards normal cells. However, it can easily be degraded after administration so it needs to be formulated into nanoparticles to increase its resistance to enzymatic degradation. The objectives of this study were to develop a protein extract of $M$.jalapa $\mathrm{L}$. leaves (RIP-MJ) incorporated into nanoparticles conjugated with Anti-EpCAM antibodies, and to determine its cytotoxicity and selectivity in the T47D breast cancer cell line. RIP-MJ was extracted from red-flowered $M$. jalapa L. leaves. Nanoparticles were formulated based on polyelectrolyte complexation using low viscosity chitosan and alginate, then chemically conjugated with anti-EpCAM antibody using EDAC based on carbodiimide reaction. RIP-MJ nanoparticles were characterised for the particle size, polydispersity index, zeta potential, particle morphology, and entrapment efficiency. The cytotoxicity of RIP-MJ nanoparticles against T47D and Vero cells was then determined with MTT assay. The optimal formula of RIP-MJ nanoparticles was obtained at the concentration of RIP-MJ, low viscosity chitosan and alginate respectively $0.05 \%, 1 \%$, and $0.4 \%(\mathrm{~m} / \mathrm{v})$. RIP-MJ nanoparticles are hexagonal with high entrapment efficiency of $98.6 \%$, average size of $130.7 \mathrm{~nm}$, polydispersity index of 0.380 and zeta potential $+26.33 \mathrm{mV}$. The IC $_{50}$ values of both anti-EpCAM-conjugated and non-conjugated RIP-MJ nanoparticles for T47D cells (13.3 and $14.9 \mu \mathrm{g} / \mathrm{mL})$ were lower than for Vero cells $(27.8$ and $33.6 \mu \mathrm{g} / \mathrm{mL})$. The $\mathrm{IC}_{50}$ values of conjugated and nonconjugated RIP-MJ for both cells were much lower than $\mathrm{IC}_{50}$ values of non-formulated RIP-MJ (>500 $\left.\mu \mathrm{g} / \mathrm{mL}\right)$.
\end{abstract}

Keywords: Ribosome-inactivating protein - Mirabilis jalapa L. nanoparticle - chitosan - alginate - anti-EpCAM

Asian Pac J Cancer Prev, 17 (4), 2277-2284

\section{Introduction}

Breast cancer is the most commonly diagnosed cancer in women. Indonesia has the highest mortality rates per 100.000 in 2008 among the ASEAN countries by $36.2 \%$ (Kimman et al., 2012). High cancer mortality rates, especially in Indonesia, can be attributed to ineffective therapy. The most common cancer therapy nowadays is chemotherapy and radiotherapy which have low selectivity that leads to systemic toxicity (Peer et al., 2007). Therefore, the development of targeted-therapy using protein from natural products is considered important since proteins have lower toxicity on normal cells and behave more predictably in vivo (Frokjaer and Otzen, 2005).

Mirabilis jalapa L. (four o'clock plants) were found to contain ribosome-inactivating protein (RIP) which has anticancer properties (Vivanco et al., 1999). RIP irreversibly inactivates ribosome through specific mechanism known as site-specific rRNA N-glikosidase activity (Barbieri et al., 1993; Stirpe, 2004). Ikawati et al. (2006) isolated RIP-like protein with molecular weight of $30 \mathrm{kDa}$ from M. jalapa L. leaves, called MJ-30, which was toxic against T47D and SiHa cells. M.jalapa L. leaves also contains an acidic RIP-like protein that is not attached to CM-sepharose CL-6B column called MJ-C protein. MJ-C possesses cytotoxic activity on cancer cells (Sudjadi et al., 2007, Sismindari et al., 2010). MJ-30 induces apoptosis in HeLa cells (Hussaana et al., 2010), while MJ-C possesses antiangiogenesis activity (Indrayudha et al., 2011). Those study show that RIP from M.jalapa L. leaves wa potential as anticancer candidate. However, the use of protein as therapeutic agent is limited due to its rapid elimination through enzymatic degradation (Torchilin and Lukyanov, 2003). To overcome this disadvantage, RIP is formulated into nanoparticles using alginate and chitosan.

Nanotechnology has been developed as an advanced protein delivery system (Grenha et al., 2004; Amidi et al., 2010; Zhang et al., 2010). Biopolymeric nanopar-ticles

${ }^{1}$ Postgraduate School of Biotechnology, ${ }^{2}$ Faculty of Pharmacy, Universitas Gadjah Mada, Yogyakarta, Indonesia *For correspondence: sismindari@ugm.ac.id 
such as alginate and chitosan are now widely used due to its biocompatibility, biodegradability and mucoadhesive properties (Sarmento et al., 2007). Alginate is a linear unbranched polymer that consists of (1-4')-linked $\beta$-D-mannuronic acid and $\alpha$-L-guluronic acid residues (Gombotz dan Wee, 1998). Chitosan consists of $\beta-(1,4)-$ linked 2-amino-2-deoxy- $\beta$-D-glucose. Alginate and chitosan are able to form particles spontaneously through polyelectrolyte complex mechanism (Hamman, 2010). Previous studies reported that chitosan and alginate has been developed into nanoparticles to deliver insulin (Sarmento et al., 2007) therefore this system can be a promising method to deliver RIP for cancer therapy.

Most of the patients suffer from systemic toxicity due to the failure of cancer drugs and therapies to differentiate between cancerous and normal cells. Therefore, developing cancer targeted-therapy is very promising, especially active-targeting nanoparticle. This nanoparticle is fabricated by conjugating nanoparticle surface with ligand which binds to specific receptors on the cancer cell surface. In this study, RIP-MJ nanoparticles were conjugated with anti-EpCAM antibody to elevate their selectivity as a novel targeted-therapy for breast cancer.

Epithelial Cell Adhesion Molecule (EpCAM/CD326) is a transmembrane glicoprotein that plays a crucial role in epithelial cell adhesion, migrasion, and metastasis. EpCAM is also discovered as a highly immunogenic tumour-associated antigen (Baeuerle and Gires, 2007). EpCAM is found to be expressed in normal breast tissue and overexpressed in breast carcinoma. Osta et al. (2004) studied EpCAM expression in MCF-7 cells as breast cancer model and discovered that EpCAM was a potential target for breast cancer therapy since it was expressed 100 times higher in breast cancer cells than that in normal cells.

\section{Materials and Methods}

\section{Materials}

The fresh leaves of red-flowered $M$. jalapa L. was collected from Pogung, Sleman, Yogyakarta, pET28a+ was obtained from Laboratory of Microbiology, Department of Fisheries, Faculty of Agriculture, Universitas Gadjah Mada, and T47D and Vero cell culture (ATCC®) from Life Science Laboratory, LPPT-UGM. Natrium alginate (Shadong Bio-Technologi, Shanghai), low viscousity chitosan (Sigma Aldrich, MO, USA), anti-EpCAM antibody clone AUA-1 (Abcam).

\section{RIP M. jalapa L. (RIP-MJ) extraction}

Fresh leaves of M.jalapa L. were homogenised using phosphate buffer pH 7.2 containing $0,14 \mathrm{M} \mathrm{NaCl}$, and then filtrated. The filtrates were centrifuged at $8.500 \mathrm{~g}$ $\left(4^{\circ} \mathrm{C}\right)$ for 40 minutes. The supernatant was precipitated in acetone and subsequently centrifuged at $8.500 \mathrm{~g}\left(4^{\circ} \mathrm{C}\right)$ for 30 minutes. The precipitated protein were disoleved in $50 \mathrm{mM}$ phosphate buffer $\mathrm{pH} 6.5$, then centrifuged again $8.500 \mathrm{~g}\left(4^{\circ} \mathrm{C}\right)$ for 30 minutes (Sismindari et al., 2010). The protein extracts were freeze-dried and stored at -20 oC. This protein extract was named RIP-MJ. Protein concentration was determined using Bradford protein assay (Bio-rad) as total protein.

\section{Determination of protein concentration}

Briefly, $4 \mu \mathrm{L}$ of supercoiled DNA (pET28a+) were incubated with $2 \mu \mathrm{L}$ of TMN buffer $10 \mathrm{x}$ and $4 \mu \mathrm{L}$ of series amount of RIP-MJ $(0.2,0.4$ dan $2 \mu \mathrm{g})$. As control, RIP-MJ was substituted with $4 \mu \mathrm{L}$ of aquabidestillata. The mixtures were incubated for 1 hour at room temperature. At the end of reaction, $4 \mu \mathrm{L}$ of loading dye was added and electrophoresis was carried out in $1 \times$ TBE buffer in $0.8 \%$ agarose gel. DNA bands were visualized by staining with ethidium bromide (Sismindari et al., 1998).

Determination of RIP-MJ activity by supercoiled DNA cleavage

Briefly, $4 \mu \mathrm{L}$ of supercoiled DNA (pET28a+) were incubated with $2 \mu \mathrm{L}$ of TMN buffer $10 \mathrm{x}$ and $4 \mu \mathrm{L}$ of series amount of RIP-MJ $(0.2,0.4$ dan $2 \mu \mathrm{g})$. As control, RIP-MJ was substituted with $4 \mu \mathrm{L}$ of aquabidestillata. The mixtures were incubated for 1 hour at room temperature. At the end of reaction, $6 \mu \mathrm{L}$ of each sample were added with $4 \mu \mathrm{L}$ of loading dye. Electrophoresis was carried out in $1 \times \mathrm{TBE}$ buffer in $0.8 \%$ agarose gel. DNA bands were visualized by staining with ethidium bromide (Sismindari et al., 1998).

Optimisation of alginate-chitosan nanoparticle formula

Aqueous stock solution of alginate $(1 \% \mathrm{~b} / \mathrm{v})$ was prepared by dissolving it in aquadest, while chitosan $(1 \% \mathrm{~b} / \mathrm{v})$ was dissolved in acetate buffer $\mathrm{pH} 4.500 \mu \mathrm{L}$ alginate and $500 \mu \mathrm{L}$ chitosan in series of concentration were homogenised for 10 seconds (Sæther et al., 2008). The optimum formula were then subsequently optimised with BSA as the protein model. $500 \mu \mathrm{L}$ alginate were homogenised with $500 \mu \mathrm{L}$ BSA for 10 seconds. $500 \mu \mathrm{L}$ chitosan were subsequently added to the mixture and were homogenised again for 10 seconds (Hu et al., 2012).

\section{Formulation of RIP-MJ nanoparticle}

Formulation of RIP-MJ nanoparticle was conducted based on Sæther et al. (2008) and Hu et al. (2012). Three (3) $\mathrm{mL}$ of $0.05 \% \mathrm{~b} / \mathrm{v}$ RIP-MJ solution were added to 3 $\mathrm{mL}$ of $0.4 \% \mathrm{~b} / \mathrm{v}$ alginate solution under constant stirring, followed by the addition of $3 \mathrm{~mL} 1 \% \mathrm{~b} / \mathrm{v}$ chitosan solution. RIP-MJ nanoparticles were formed spontaneously. The nanoparticle suspension was then dialysed overnight at $4^{\circ} \mathrm{C}$.

\section{Determination of entrapment efficiency}

Nanoparticle entrapment was calculated by measuring the total RIP MJ used in the reaction and the amount of free RIP MJ in the suspension following the reaction process. This protein assay was done using Bradford method at the absorbance at $595 \mathrm{~nm}$ on spectrophotometer (Genesys 10UV scanning, Thermo Scientific). The value of entrapment efficiency (EE) was calculated as follows:

$$
\mathrm{EE} \%=\frac{(\text { Total amount Protein-Free protein })}{(\text { Total amount protein })} \times 100 \%
$$

(Gan and Wang, 2007)

Conjugation of Anti-EpCAM antibody on RIP-MJ nanoparticle 
Mirabilis jalapa L. Ribosome-Inactivating Protein Nanoparticles with Anti-Epcam Antibodies Against T47D Cells

Anti-EpCAM antibody was chemically conjugated on the nanoparticle surface based on carbodiimide reaction which modified from Interchim (2008). Ten (10) $\mu \mathrm{L} 1 \mu \mathrm{g} /$ $\mu \mathrm{L}$ anti-EpCAM were mixed with $10 \mu \mathrm{L}$ of $1 \mu \mathrm{g} / \mu \mathrm{LEDAC}$ and $80 \mu \mathrm{L}$ of $20 \mathrm{mM}$ MOPS buffer $\mathrm{pH} 6$. The mixture was then incubated for 15 menit at room temperature, and $50 \mu \mathrm{L}$ of antibody-EDAC mixture was added to $5 \mathrm{~mL}$ of RIP-MJ nanoparticle suspension. Nanoparticle-antibody mixture was dialysed overnight at $4^{\circ} \mathrm{C}$.

\section{Characterisation of RIP-MJ nanoparticle morphology}

RIP-MJ nanoparticle morphology was visualised at Department of Chemistry, Faculty of Mathematics and Natural Science, Universitas Gadjah Mada Yogyakarta. Nanopar-ticle sample was stained with phosphotungstic acid, dropped on a copper grid, then visualized using transmission electron microscope (JOEL-JEM 1400, Japan) (de Campos et al., 2004).

Measurement of RIP-MJ nanoparticle size, polydispersity index, and zeta potential

Measurement of RIP-MJ nanoparticle size, polydispersity index, and zeta potential was conducted at Balai Inkubator Teknologi, Badan Pengkajian dan Penerapan Teknologi (BIT-BPPT) Serpong, Tangerang. 2 drops of nanoparticle suspension were homogenized with $5 \mathrm{~mL}$ of aquadest. $3 \mathrm{~mL}$ of the mixture were analysed using DelsaTM Nano Submicron Particle Size Analyser (Beckman Coulter) (Kocbek et al., 2007).

Cytotoxicity of RIP-MJ nanoparticle on T47D and Vero Cell lines

Cytotoxicity assay was conducted at Life Science Laboratory LPPT-UGM. Cell culture of T47D cells and Vero cells were maintained in RPMI 1640 and M199 medium respectively. One hundred (100) $\mu \mathrm{L}$ of cell suspension $\left(1 \times 10^{4}\right.$ cells $\left./ 100 \mu \mathrm{L}\right)$ were placed into 96 -well microplate followed by starvation and incubation for 24 hours. The cells were treated with $100 \mu \mathrm{L}$ of conjugatedand unconjugated- RIP-MJ nanoparticles at various concentrations. The cells were further incubated for 3 hours followed by washing with PBS.

The number of viable cells was ascertained with MTT reaction (3-(4,5-dimethyltiazol-2-il)-2,5-diphenyl tetrazolium bromide), and measured at $\lambda_{550} \mathrm{~nm}$ followed by $\mathrm{IC}_{50}$ calculation (Mosmann, 1983; Lu et al., 2009). The effect of all treatments on the proliferation of T47D and Vero cells was expressed as the percentage (\%) dead cell, using the following formula:

$$
\% \text { dead cell }=\frac{\text { OD control cell-OD treated cell }}{\text { OD control cell }} \times 100 \%
$$

Inhibitory concentration of $50 \%\left(\mathrm{IC}_{50}\right)$ was determined by converting the percentage of dead cells using probit analysis.

\section{Results and Discussion}

\section{Extraction and activity of RIP-MJ}

RIP-MJ extraction process from fresh $M$. jalapa L. resulted of $38 \%$ proteins. The extract protein activity before and after freeze-drying were determined by supercoiled DNA cleavage. RIP-MJ at 0.2 and $0.4 \mu \mathrm{g}$

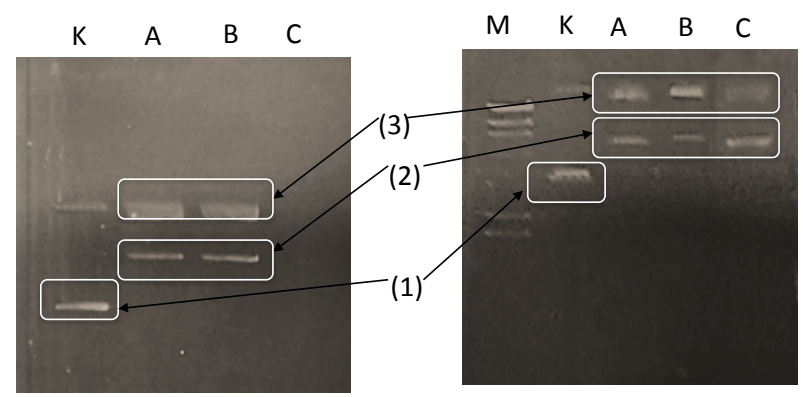

Figure 1. Effect of RIP-MJ on the Plasmid DNA Cleavage (pET28). A and B, indicated before and after freeze-drying process of RIP-MJ. Lane M shows DNA marker Lambda Hind III; lane K shows control untreated DNA plasmid; Lane A, B, and C shows treated DNA plasmid with $0.2,0.4$, and $2 \mu \mathrm{g}$ of RIP-MJ respectively. RIP-MJ at $0.2 \mu \mathrm{g}$ and $2 \mu \mathrm{g}$ were able to cleave (1) supercoiled DNA into (2) linear and (3) nick-sirkular DNA. RIP-MJ at the weight of $2 \mu \mathrm{g}$ before freeze-drying did not form any bands of DNA, indicated that the DNA might be fully degraded by RIP-MJ

Table 1. Optimisation of alginate and low viscousity chitosan

\begin{tabular}{cccccc}
\hline $\begin{array}{c}\text { Alginate } \\
\text { Concentration }\end{array}(\%)$ & \multicolumn{5}{c}{ Chitosan Concentration (\%) } \\
\cline { 2 - 6 } & 0.01 & 0.05 & 0.1 & 0.5 & 1 \\
\hline 0.01 & Clear & clear & clear & clear & clear* \\
0.05 & Clear & clear & clear & clear & clear* \\
0.1 & Clear & clear & clear & clear & clear* \\
0.5 & Clear & clear & opaque & precipitation & precipitation \\
1 & Clear & clear & opaque & precipitation & precipitation \\
\hline
\end{tabular}

*mark shows the chosen formula

\section{Table 2. Optimisation of Nanoparticle Formula Using BSA as Protein Mode}

\begin{tabular}{|c|c|c|c|c|c|c|}
\hline \multirow{2}{*}{$\begin{array}{c}\text { Chitosan } \\
\text { Concentration } \\
(\%)\end{array}$} & \multirow{2}{*}{$\begin{array}{c}\text { BSA } \\
\text { Concentration } \\
(\%) \\
\end{array}$} & \multicolumn{5}{|c|}{$\begin{array}{c}\text { Alginate Concentration } \\
(\%)\end{array}$} \\
\hline & & 0.1 & 0.2 & 0.3 & 0.4 & 0.5 \\
\hline \multirow{5}{*}{1} & 0.01 & Clear & clear & clear & opaque & precipitation \\
\hline & 0.05 & Clear & clear & clear & opaque & precipitation \\
\hline & 0.1 & Clear & clear & clear & opaque & precipitation \\
\hline & 0.5 & Clear & clear & clear & opaque* & opaque* \\
\hline & 1 & Clear & clear & precipitation & precipitation & precipitation \\
\hline
\end{tabular}

*mark shows the chosen formula 
Table 3. Formulation and Entrapment Efficiency of RIP-MJ nanoparticles

\begin{tabular}{ccccc}
\hline $\begin{array}{c}\text { Alginate Concentration } \\
(\%)\end{array}$ & $\begin{array}{c}\text { Chitosan Concentration } \\
\text { Concentration }\end{array}$ & $\begin{array}{c}\text { RIP-MJ } \\
\text { Solution Visualisation }\end{array}$ & \multicolumn{2}{c}{ Entrapment Efficiency } \\
\hline \multirow{2}{*}{0.4} & $(\%)$ & 0.05 & clear* & 98.57 \\
& \multirow{2}{*}{1} & 0.1 & clear & 94.51 \\
& & 0.2 & opaque & 90.54 \\
\hline
\end{tabular}

*mark shows the chosen formula

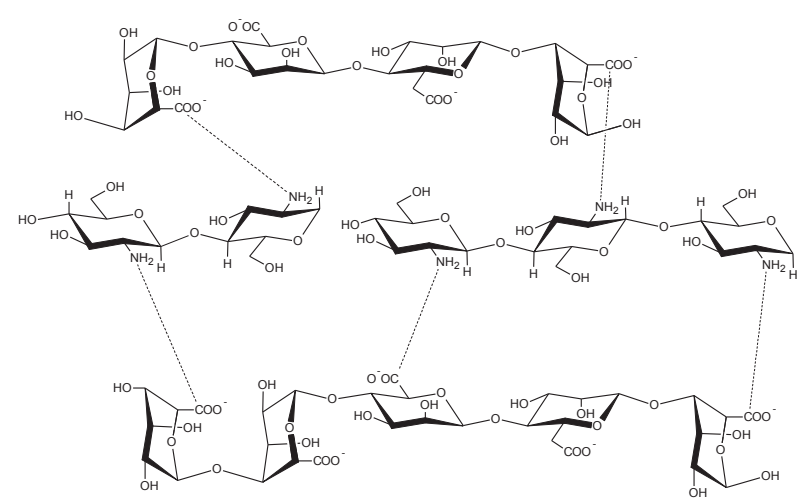

Figure 2. Polyelectrolyte Complexation by Alginate, chitosan, and RIP-MJ. Amine groups (-NH2) of chitosan bind to carboxyl groups (-COOH) of alginate, and RIP-MJ is encapsulated within the polymeric matrix

before (Figure. 1a lane A-B) and after freeze-drying (Figure 1b lane A-B) showed the ability to cleave supercoiled DNA, as indicated by the formation of two DNA bands, linear and nick-circular DNA.

It was reported that protein fraction isolated from $M$. jalapa L. roots was able to cleave supercoiled DNA at a $2 \mathrm{mg}$ proteins Ikawati et al. (2002), while from M.jalapa L. seeds showed the activity at $1 \mathrm{mg}$ proteins (Sudjadi et al., 2002). It was also reported that MJ-30 show the ability of supercoiled DNA cleavage at $11.52 \mu \mathrm{g}$ proteins (Ikawati et al. 2006). The amount of RIP-MJ needed to cleave supercoiled DNA in this study is much lower than that of the previous ones, probably because RIP-MJ was still crude extract, so that there are other proteins which increase the cleavage activity. Ling et al. (1994) suggested that RNA N-glycosidase activity of RIP somehow related to its ability to cleave the supercoiled DNA. The freezedrying proses in this result, seemed not affected the RIPMJ activity, that's means that the protein seemed to have good stability. Ling et al. (1994) reported that chain A ricin still showed cleavage activity after boiled for 10 minutes. From this we can conclude that the change of temperature does not affect RIP activity.

\section{Optimisation alginate-low viscousity chitosan nanoparticle} formula

Nanoparticles were formulated through polyelectrolyte complex (PEC) method. The optimisation was conducted in two phases. Phase one was conducted to optimise the composisition of polymers that was to form nanoparticle spontaneously. Table 1 shows the visualisation of chitosan and alginate mixture. The higher of the polymers concentration used in the mixture, the larger particles were formed. If the polymers were used in very high

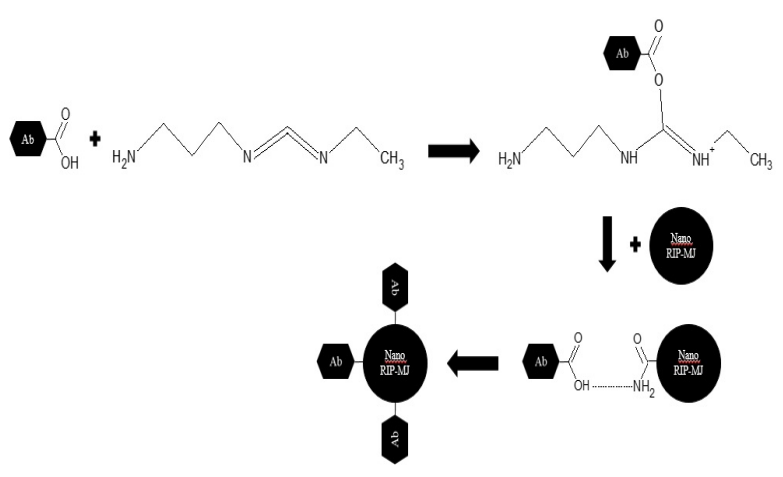

Figure 3. The Role of Carbodiimide on the Conjugation Reaction of RIP-MJ Nanoparticle and Anti-EpCAM Antibody Using. EDAC forms amide bond between amine group and carboxyl group. In this process, carboxyl groups of anti-EpCAM bound to amine groups of chitosan. (modified from East et al., 2011)

concentration, precipitation or gel aggregation could also be formed. Nanoparticles do not settle because of Brownian motion. Brownian motion is defined as random movement among particles in the suspension. Macro-particles settle out of suspension because gravity is stronger than Brownian motion among the particles. On the contrary, since the gravitational pull is not stronger than Brownian motion, gravity does not affect nanoparticle so that they do not easily settle and are relatively stabile in a long time of storage (Gupta, 2006).

The formulas which were chosen from the first phase of optimisation used was $1 \%$ chitosan and $0.01 \%, 0.05 \%$, $0.1 \%$ alginate (Table 1). Those formulas formed clear solution right before precipitated at alginate concentration of $0.5 \%$. All the chosen formulas used $1 \%$ chitosan since it was assumed that the higher the concentration of chitosan, the more amine groups provided to be conjugated with carboxyl group of alginate. The formulas that used 0.1 and $0.5 \%$ alginate gave different visualisation, therefore further optimisation used alginate in concentration of 0.1 , $0.2,0.3,0.4$, and $0.5 \%$ (Table 2).

The formula that would be formulated further using RIP-MJ were $0.4 \%$ alginate, $1 \%$ chitosan, and $0.5 \%$ BSA. The formula using $0.4 \%$ alginate formed a suspension with smaller particle than the one using $0.5 \%$ alginate, therefore this formula was chosen to be further developed through conjugation with anti-EpCAM antibody.

Formulation and entrapment efficiency of RIP-MJ nanoparticles

The formula of RIP-MJ nanoparticles were at first optimised by formulating nanoparticles using 3 RIP-MJ concentrations $0.05,0.1$ and $0.2 \%(\mathrm{~m} / \mathrm{v})$. The entrapment 
Mirabilis jalapa L. Ribosome-Inactivating Protein Nanoparticles with Anti-Epcam Antibodies Against T47D Cells

Table 4. Characterization of anti-EpCAM-conjugated RIP-MJ nanoparticles

\begin{tabular}{lccc}
\hline \multicolumn{1}{c}{ Formula } & $\begin{array}{c}\text { Particle } \\
\text { Size } \\
(\mathrm{nm})\end{array}$ & $\begin{array}{c}\text { Polydispersity } \\
\text { Index }\end{array}$ & $\begin{array}{c}\text { Zeta } \\
\text { Potential } \\
(\mathrm{mV})\end{array}$ \\
\hline $\begin{array}{l}\text { 0.4\% Alginate }-1 \% \\
\text { Chitosan }-0.05 \%\end{array}$ & 130.73 & 0.380 & +26.36 \\
RIP-MJ & & & \\
\hline
\end{tabular}

Table 5. IC $_{50}$ value of RIP-MJ Nanoparticles Against T47D and Vero Cell Lines

\begin{tabular}{lcc}
\hline \multirow{2}{*}{ Treatment } & \multicolumn{2}{c}{ IC $_{\mathbf{5 0}}$ Value } \\
\cline { 2 - 3 } & T47D & Vero \\
\hline $\begin{array}{l}\text { Anti-EpCAM-conjugated RIP-MJ } \\
\text { nanoparticles }\end{array}$ & 13,27 & 33,62 \\
$\begin{array}{l}\text { Unconjugated RIP-MJ } \\
\text { nanoparticles }\end{array}$ & 14,87 & 27,84 \\
Native RIP-MJ & $1,842,025$ & $1,387,868$ \\
\hline
\end{tabular}

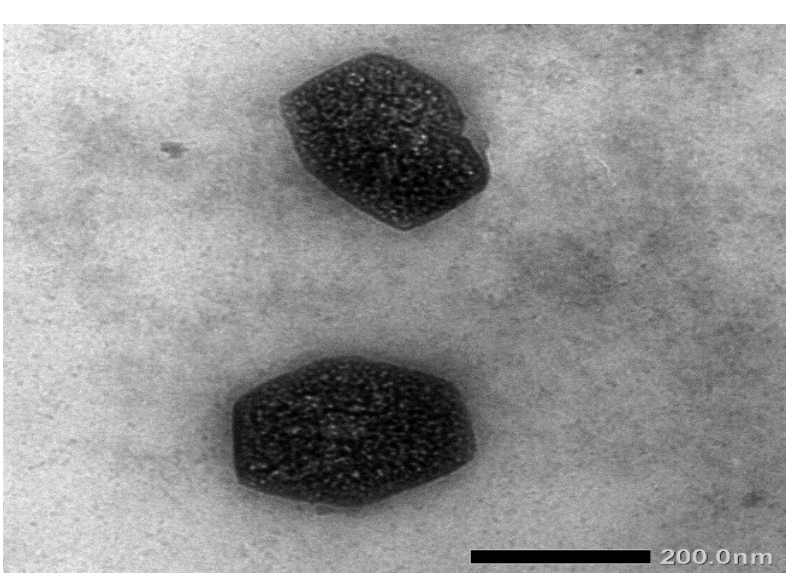

Figure 4. Morphology of Anti-EpCAM-Conjugated RIP-MJ Nanoparticles. TEM visualisation showed that the nanoparticles were hexagonal and not forming aggregation

efficiency of those formulas was determined and the results are shown in Table 3.

Nanoparticle formula which used alginate $0.4 \%$, chitosan $1 \%$ and RIP-MJ $0.05 \%(\mathrm{~m} / \mathrm{v})$ was chosen to be scaled-up due to its high EE. The nanoparticles were formed spontaneously through PEC between alginate and chitosan. The amine group of chitosan binds to carboxyl group of alginate. RIP-MJ was encapsulated within the polymer matrix thus leads to the formation of proteinloaded nanoparticles.

RIP-MJ nanoparticles showed high EE of $98.57 \%$ (Tabel 3). Sarmento et al. (2007) reported the EE of insulin-loaded alginate-chitosan nanoparticles was $72.8 \%$. However, they used slightly different preparation method by preparing alginate-calcium chloride pregelation followed by chitosan complexation. Therefore, nanoparticle preparation method and the protein used in formulation affects the $\mathrm{EE}$ of nanoparticles.

Conjugation and characterisation of anti-EpCAMconjugated RIP-MJ nanoparticle

Anti-EpCAM antibody was chemically conjugated on the nanoparticle with EDAC based on carbodiimide reaction (Figure 3). EDAC forms amide bond between

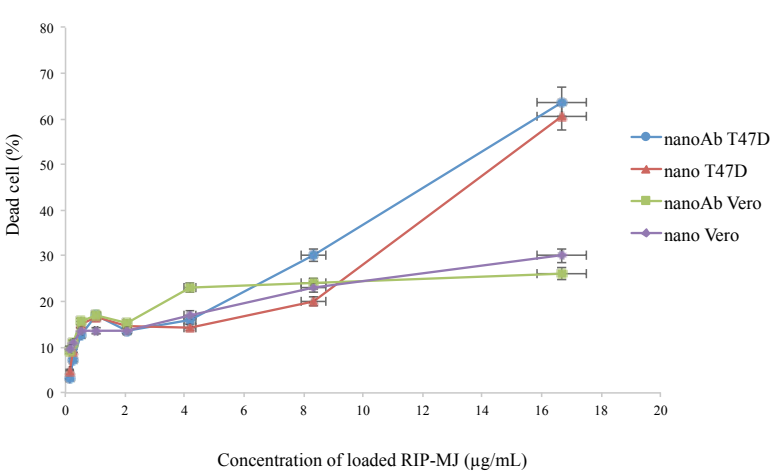

Figure 5. Cytotoxic Effects of RIP-MJ Nanoparticles Against T47D and Vero Cell-Lines. T47D and Vero cells were treated with anti-EpCAM-conjugated and unconjugated RIP-MJ nanoparticles, followed by incubation for 3 hours. The data was obtained with three measurements in one experiment. Anti-EpCAM-conjugated and unconjugated nanoparticle containing RIP-MJ at $16.67 \mu \mathrm{g} / \mathrm{mL}$ was more cytotoxic to T47D compare to Vero cells-lines

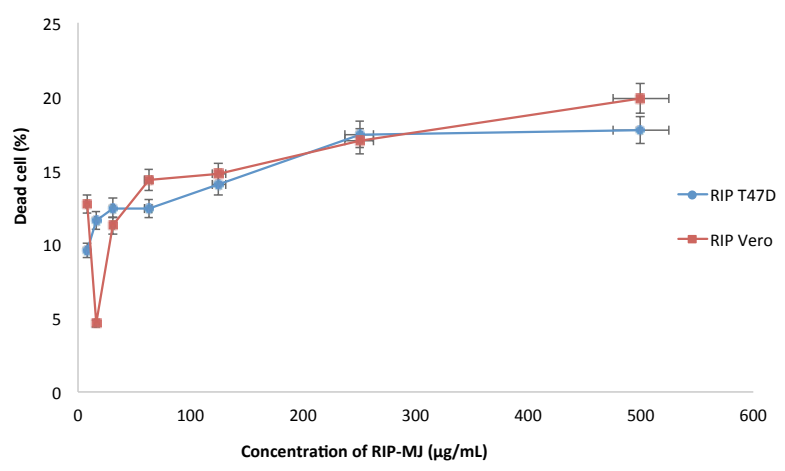

Figure 6. Cytotoxic Effects of Native RIP-MJ Against T47D and Vero Cell-Lines. T47D and Vero cells were treated with native RIP-MJ at various concentrations. Incubation was carried out for 3 hours. The data was obtained with three measurements in one experiment. At the concentration of 500 $\mu \mathrm{g} / \mathrm{mL}$, native RIP-MJ has low cytotoxicity against T47D and Vero with the inhibition of $17.71 \%$ and $19.87 \%$ respectively

amine group and carboxyl group. After EDAC activated the carboxyl groups of anti-EpCAM, the antibody was subsequently mixed in nanoparticle solution. In this process, carboxyl groups of anti-EpCAM bound to amine groups of chitosan.

Anti-EpCAM-conjugated RIP-MJ nanoparticle morphology was visualised using transmission electron microscope. Figure 4 shows that the nanoparticles were hexagonal and not forming aggregation. Lu et al. (2009) developed mesoporous silica nanoparticles with the size of $110 \mathrm{~nm}$. The particles showed the same morphological characteristics with RIP-MJ nanoparticles in this study.

Anti-EpCAM-conjugated RIP-MJ nanoparticles were formed with average size of $130.73 \mathrm{~nm}$. RIP-MJ nanoparticles are on the appropriate size since nanoparticle made by soft polymer with melting point below $300 \mathrm{oC}$ are desired to be smaller than $<300 \mathrm{~nm}$ (Gupta, 2006). Nanoparticle that smaller than $280 \mathrm{~nm}$ is also applicable to deliver drugs through capillary blood vessel (Lu et al., 2009).

Particle size might be affected by molecular weight of the polymers (Vauthier and Bouchemal, 2009), 


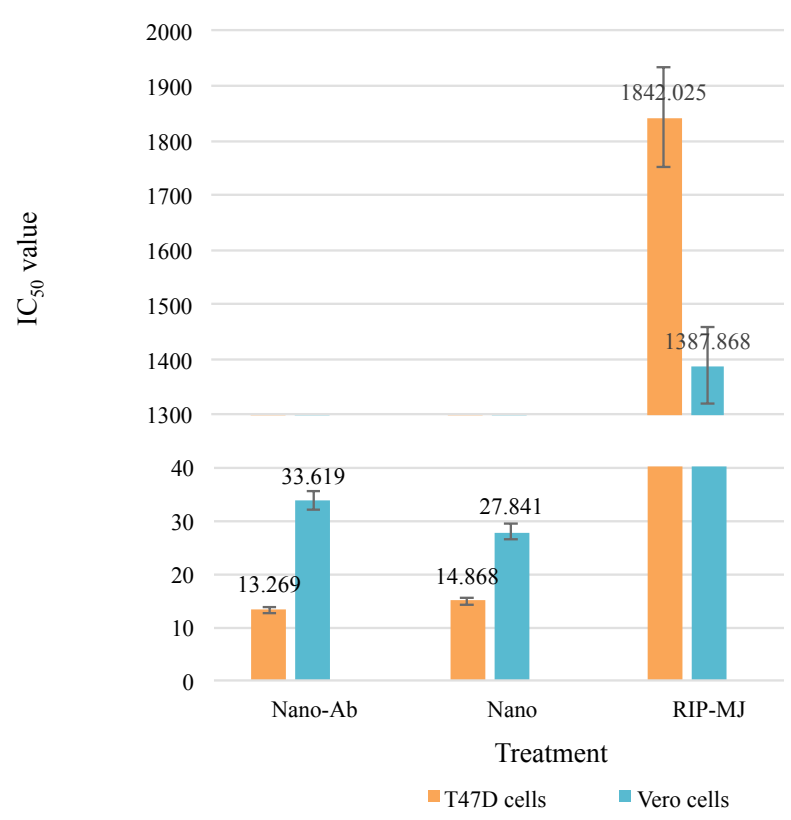

Figure 7. IC $_{50}$ Value of RIP-MJ Nanoparticles Against T47D and Vero Cells-Lines. The $\mathrm{IC}_{50}$ values of antiEpCAM-conjugated and unconjugated RIP-MJ nanoparticles (Nano-Ab and Nano) on T47D cells are lower than that on Vero cells, indicating that RIP-MJ nanoparticles were considerably toxic to T47D cells than Vero cells. The IC50 values of RIPMJ nanoparticles on both cell lines are also lower than that of native RIP-MJ

nanoparticle preparation method (Sundar et al., 2010), and polymer mixing order (Sæther et al., 2008). Mohanraj and Chen (2006) stated that particle size affects the loading capacity, drug release and stability of nanoparticles. Cellular uptake also depends on the particle size. The cellular uptake of the particles increased with decreasing size (Lu et al., 2009). Smaller particles also have larger surface area. Drugs loaded onto the particles are exposed to the surface so that they will be released faster (Sundar et al., 2010).

Polydispersity index (PI) shows the particle size distribution. According to Nidhin et al. (2008), monodispersed nanoparticles have PI value of 0.01-0.5 while polydispersed ones have PI values $>0.7$. Therefore, RIP-MJ nanoparticles are classified as polydisperse since the PI value was 0.380 .

Zeta potential shows not only the surface charge, but also the stability of RIP-MJ nanoparticles. Nanoparticles show good stability in suspension when the zeta potential above (-/+) $30 \mathrm{mV}$ (Mohanraj and Chen, 2006). In this study, we used chitosan $1 \%$ and alginate $0.4 \%$. In excess of chitosan, the obtained nanoparticles should have highly positive zeta potential (Sæther et al., 2008). Nevertheless, zeta potential of RIP-MJ nanoparticles was $+26.36 \mathrm{mV}$ (Table 4 ), in range between $-30 \mathrm{mV}$ and $+30 \mathrm{mV}$. This could be due to the presence of RIP-MJ which probably affected the ionic interaction between alginate and chitosan during PEC formation. Nano-particle surface charge plays a crucial role in facilitating nanoparticle internalisation into the cell. Since the cell membrane consists of highly-anionic glycosaminoglycans, positivecharged nanoparticles will internalise into the cell more easily due to the ionic interactions (Hartig et al., 2007).
Cytotoxicity of Anti-EpCAM-conjugated RIP-MJ nanoparticle on T47D and Vero Cells

The cytotoxic effects of anti-EpCAM-conjugated RIPMJ nanoparticle were evaluated at T47D and Vero cells. The cytotoxicity assay was conducted to determine the toxicity of RIP-MJ nanoparticle on T47D and Vero cells, and to determine the role of anti-EpCAM in facilitating the nanoparticle to enter the cells.

Figure 5 shows that the percentage of dead cell decreases as the concentration of RIP-MJ in the nanoparticle decreases. Anti-EpCAM-conjugated and unconjugated nanoparticle containing RIP-MJ of 16.67 $\mu \mathrm{g} / \mathrm{mL}$ were able to inhibit T47D cell proliferation of $63.71 \%$ and $60.62 \%$ cell proliferation respectively. At the same RIP-MJ concentration, anti-EpCAM-conjugated and unconjugated RIP-MJ nanoparticles inhibit Vero cell proliferation of $26.13 \%$ and $30.04 \%$ respectively. Figure 5 also demonstrates that RIP-MJ nanoparticles inhibit more T47D cells than Vero cells.

Figure 6 demonstrates the percentage of dead T47D and Vero cells under the treatment of natine RIP-MJ. At the highest concentration of native RIP-MJ $(500 \mu \mathrm{g} / \mathrm{mL})$, the proliferation of T47D and Vero cells were inhibited by $17.71 \%$ and $19.87 \%$ respectively.

Table 5 and Figure 7 demonstrate the comparison of $\mathrm{IC}_{50}$ value of T47D and Vero cells under the treatment of RIP-MJ nanoparticles and native RIP-MJ. T47D cell proliferation were inhibited by anti-EpCAM-conjugated RIP-MJ nanoparticles with $\mathrm{IC}_{50}$ value of $13.269 \mu \mathrm{g} / \mathrm{mL}$ of loaded RIP-MJ concentration, while the $\mathrm{IC}_{50}$ value of T47D cells treated with unconjugated nano-particles is $14.868 \mu \mathrm{g} / \mathrm{mL}$. On the other hand, the $\mathrm{IC}_{50}$ value of Vero cells treated with anti-EpCAM-conjugated and unconjugated RIP-MJ nanoparticles are $33.619 \mu \mathrm{g} / \mathrm{mL}$ and $27.841 \mu \mathrm{g} / \mathrm{mL}$ respectively. These results indicate that RIP-MJ nanoparticles were considerably toxic to T47D cells than Vero cells.

The $\mathrm{IC}_{50}$ values of both conjugated- and unconjugatedRIP-MJ nanoparticles are lower than that of native RIP-MJ on both cells $(>500 \mu \mathrm{g} / \mathrm{mL})$. The $\mathrm{IC}_{50}$ value of the cells that were treated with nanoparticles and native RIP-MJ are significantly different because native RIP-MJ were not probably be able to enter the cell in 3 hours. Cell membrane has low permeability to macromulecules (Torchilin dan Lukyanov, 2003), including protein such as RIP-MJ. Additionally, RIP-MJ is classified as type 1 RIP which is known to have difficulty in entering the cell (Barbieri et al., 1993).

RIP-MJ nanoparticles enter the cell through ionic interaction between nanoparticle surface and cell membrane. Cell membrane consists of highly anionic glycosaminoglycans while nanoparticle surface is positive-charged. The interaction between the two different charges facilitates RIP-MJ nanoparticles to enter the cell via endocytosis (Hartig et al., 2007). The same interaction does not probably occur between native RIP-MJ and cell membrane. The ionic interaction helps RIP-MJ nanoparticle to enter the cell within the incubation time. This explains the higher percentage of dead cell in RIP-MJ nanoparticle administration compared to that in the native RIP-MJ treatment. 
Mirabilis jalapa L. Ribosome-Inactivating Protein Nanoparticles with Anti-Epcam Antibodies Against T47D Cells

Figure 7 proposed that the $\mathrm{IC}_{50}$ of RIP-MJ nanoparticles were much lower than that of the native RIP-MJ. This phenomenon was related to the comparable size between the nanoparticles and native RIP-MJ. Moreover, as we mentioned before, the ionic interaction between the native RIP-MJ and cell surface was more difficult to occur. RIP-MJ nanoparticles will be easily passing through cell membrane and engulfed by lysosomes. Inside the lysosomes, chitosan was protonated and enzymatically degraded. The protonation induced the change of osmotic pressure leading to disruption of lysosome membrane so that the nanoparticles successfully entered the cytoplasm. In addition, the protonation causes chitosan to swell yet still allow it to protect the encapsulated protein (Panyam and Labhasetwar, 2003; Hashimoto et al., 2005). Gan and Wang (2007) reported that nanoparticles enter the cell in 3 hours, after that the protein will be gradually released through a sequence of degradation in 6 hours. RIP-MJ nanoparticles were relatively small so that the protein could be rapidly released, so that RIP-MJ could induce the cell death in the next 24 hours. From this we can conclude that the formulation of RIP-MJ into nanoparticles increases the efficacy of the protein in entering cancer cells. The $\mathrm{IC}_{50}$ of RIP-MJ nanoparticles on T47D were lower than on Vero cells, thus it was assumed that RIP-MJ nanoparticles preferably entered T47D cells than Vero cells. Nevertheless, the mechanism of this preference, whether it is due to the conjugated antibody on the nanoparticle surface, is still unknown. Sterzynska et al. (2012) reported that EpCAM clone AUA-1 was negatively expressed on T47D cells. It was assumed that the permeability of T47D cell membrane to RIPMJ nanoparticle might be higher than that of Vero cells. Thus, the nanoparticles could easily penetrate to T47D cells leading to accumulation of nanoparticles in the cells.

In conclusion, Based on this study, it can be concluded that RIP-MJ could be formulated into nanoparticles for protein delivery in vitro. However, further study about the appropriate target for the therapy is needed to determine the selectivity of the therapy.

\section{Acknowledgements}

Faculty of Pharmacy UGM research grant in 2015.

\section{References}

Amidi M, Mastrobattista E, Jiskoot W, et al (2010). ChitosanBased delivery systems for protein therapeutics and antigens. Advanced Drug Delivery Rev, 62, 59-82.

Anonim (2008). Carbodiimides (EDAC) Heterobifunctionnal cross-linkers, http://www.interchim.fr/ft/5/52005A.pdf, Accessed on 21 November 2013.

Baeuerle P, Gires O (1993). EpCAM (CD326) finding it is role in cancer. Br J Cancer, 96, 417- 23.

Barbieri L, Batelli MG, Stirpe F (1993). Ribosome-inactivating proteins from plants. Biochim Biophys Acta, 1154, 237-82.

Bradford MM (1976). Rapid and sensitive method for the quantitation of microgram quantities of protein utilizing the principle of protein-dye binding. Anal Biochem, 72, 248-54.

De Campos AM, Diebold Y, Carvalho ELS, et al (2004). Chitosan nanoparticles as new ocular drug delivery systems: in vitro stability, in vivo fate, and cellular toxicity. Pharm Res, 21, 803-10.

Frokjaer S, Otzen DE (2005). Protein drug stability: a formulation challenge, Nat Rev Drug Discov, 4, 298-306.

Gan Q, Wang T (2007). Chitosan nanoparticle as protein delivery carrier-systematic examination of fabrication conditions for efficient loading and release. Colloids SurfB: Biointerfaces, 59, 24-34.

Gombotz WR, Wee SF (1998). Protein Release from alginate matrices. Adv Drug Deliver Rev, 31, 267-85.

Grenha A, Seijo B, Remuñán-López C, et al (2005). Microencapsulated chitosan nanoparticles for lung protein delivery. Eur J Pharm Sci, 25, 427-37.

Gupta RB (2006). Fundamentals of drug nanoparticles in nanoparticle technology for drug delivery, Eds Gupta RB and Kompella UB. Taylor \& Francis Group, New York pp 1-9.

Hamman JH (2010). Chitosan based polyelectrolyte complexes as potential carrier materials in drug delivery systems. Marine Drugs, 8, 1305-22.

Hartig SM, Greene RR, Dikov MM, et al (2007). Multifunctional nanoparticulate polyelectrolyte complexes. Pharm Res, 24, 2353-69.

Hashimoto M, Yang Z, Koya Y, et al (2005). Chitosan in nonviral gene therapy, gene design and delivery, Eds Taira K, Kataoka K, and Niidome T. Springer-Verlag, Tokyo, 63-74.

$\mathrm{Hu}$ C, Chiang C, Yeh (2012). Influence of charge on FITCBSA-loaded chondroitin sulfate-chitosan nanoparticles upon cell uptake in human Caco-2 cell monolayers. Int $J$ Nanomedicine, 7, 4861-72.

Hussaana A, Chodidjah, Sismindari, et al (2010). Mekanisme in vitro induksi apoptosis dari RIP (Ribosome-Inactivating Protein) daun bunga pukul empat (Mirabilis jalapa L). Jurnal Sains Medika, 2, 23-31.

Ikawati Z, Sudjadi, Sismindari (2006). Cytotoxicity against tumor cell lines of a Ribosome-lInactivating Protein (RIP)like protein isolated from Leaves of Mirabilis jalapa L. Malay J Pharm Sci, 4, 31-41.

Indrayudha P, Wijayanti N, Sismindari (2011). Antiangiogenesis activity of protein fraction containing MJ-C acidic ribosomeinactivating protein of Mirabilis jalapa L. Jurnal Bahan Alam Indonesia, 7, 277-81.

Kimman M, Norman R, Jan S, et al (2012). The burden of cancer in member countries of the association of Southeast Asian nations (ASEAN). Asian Pac J Cancer Prev, 13, 411-20.

Kocbek P, Obermajer N, Cegnar M, et al (2007). Targeting cancer cells using PLGA nanoparticles surface modified with monoclonal antibody. J Controlled Release, 120, 18-26.

Ling J, Liu W, Wang TP (2009). Cleavage of supercoiled doublestranded DNA by several ribosome-inactivating proteins in vitro. FEBS Lett, 345, 143-6.

Lu F, Wu SH, Hung Y, et al (2009). Size effect on cell uptake in well-suspended. Uniform Mesoporous Silica Nanoparticles. Small, 5, 1408-13.

Mohanraj VJ, Chen Y (2006). Nanoparticles-a review. Tropical $J$ Pharmaceutical Res, 5, 561-73.

Mosmann T (1983). Rapid colorimetric sssay for cellular growth and survival: application to proliferation and cytotoxicity assays. J Immunol Methods, 65, 55-63.

Nidhin M, Indumathy R, Sreeram KJ, et al (2008). Synthesis of iron oxide nanoparticles of narrow size distribution on polysaccharide templates. Bull Mater Sci, 31, 93-6.

Osta WA, Chen Y, Mikhitarian K, et al (2004). EpCAM is overexpressed in breast cancer and it is a potential target for breast cancer gene therapy. Cancer Res, 64, 5818-24.

Panyam J, Labhasetwar V (2003). Biodegradable nanoparticles for drug and gene delivery to cells and tissue. Advanced Drug Delivery Rev, 55, 329-47. 
Psycha Anindya Wicaksono et al

Peer D, Karp JM, Hong S, et al (2007). Nanocarriers as an emerging platform for cancer therapy. Nature Nanotechnol, 2,751-60.

Sarmento B, Ribeiro, Veiga F, et al (2007). Alginate/chitosan nanoparticles are effective for oral insulin delivery. Pharm Res, 24, 2198-206.

Sæther HV, Holme HK, Maurstad G, et al (2008). Polyelectrolyte complex formation using alginate and chitosan. Carbohydr Polym, 74, 813-21.

Sismindari, Husaana A, Mubarika S (1998). In vitro cleavage of supercoiled DNA by Annona squamosa extract. MFI, 9 , 146-52.

Sismindari, Hartati MS, Adhyatmika, et al (2010). Cytotoxic selectivity of MJC0.3 and MJC0.5, acidic ribosomeinactivating proteins isolated from Mirabilis jalapa $\mathrm{L}$. leaves against various cancer cell lines. J Med Sci, 42, 39-43.

Sterzynska K, Kempisty B, Zawierucha P, et al (2012). Analysis of the specificity and selectivity of anti-EpCAM antibodies in breast cancer cell lines. Folia Histochem Cytobiol, 50, 534-41.

Stirpe F (2004). Ribosome-inactivating proteins. Toxicon, 44, 371-83.

Sudjadi, Witasari LD, Sadarum MT, et al (2007). Efek sitotoksik suatu protein seperti ribosome-inactivating proteins yang bersifat asam dari daun Mirabilis jalapa L. pada sel kanker. MFI, 18, 8-14.

Sundar S, Kundu J, Kundu SC, et al (2010). Biopolymeric nanoparticles, Sci Technol Adv Mater, 11, 1-13.

Torchilin VP, Lukyanov AN (2003). Peptide and protein drug delivery to and into tumors: challenges and solutions, Drug Discov Today, 8, 259-66.

Vauthier C, Bouchemal K (2009). Methods for the preparation and manufacture of polymeric nanoparticles. Pharm Res, 26, 1025-58.

Vivanco JM, Querci M, Salazar LF (1999). Antiviral and antiviroid activity of MAP-containing extracts from Mirabilis jalapa L. roots. Plant Dis, 83, 1116-21.

Zhang H, Wu S, Tao Y, et al (2010). Preparation and characterization of water-soluble chitosan nanoparticles as protein delivery system. J Nanomaterials, 2010, 1-5. 